\title{
ALEXANDER LIBRARY: \\ The Past, the Present, the Future ${ }^{1}$
}

\section{BY BERYL SMITH}

Ms. Smith is Acting Head, 'Technical Services Department, Alexander L ibrary

"The public library is the treasure house of civiliwation, and the great university research library is the crown jewel of that treasure house."

\section{Clyde Hendrick ${ }^{2}$}

"It is my considered judgement that a university without an adequate library is like a book without an index or a body without a soul."

Governor Alfred E. Driscoll ${ }^{3}$

If Governor Driscoll could return to Rutgers University today, it is likely that he would consider this an institution with a lot of soul. The several campuses of the university, spread throughout the state, are supported by eighteen strategically placed libraries serving the needs of students and faculty at each location. The library to which Governor Driscoll referred, at the time of the dedication in 1956, was the Rutgers University Library, since renamed for Archibald Stevens Alexander and known as the Alexander Library. The parent library of the Rutgers University Libraries, Alexander Library has grown from historically murky beginnings into the true soul of the university. Over the 220 years since the college received its charter, the library has been housed in at least four locations and has now reached a size that requires an expanded house in which to contain the riches of the collection and the activities of the users.

With the expansion and renovation of Alexander Library in progress, and the completion date less than a year away, it seems fitting to review the development of this library and not only to look back but also to the plans for the future. It is especially important to realize that, although there were necessary economies in construction planning, the concept 
embracing the planning was to create a library that would serve, and serve with credit and honor, well into the future.

A history of Alexander Library might be only a discussion of bricks and mortar or shelves and books. In fact, early historic discussions of libraries generally focus on either or both subjects exclusively. But, as important as are the building shell and book-holding stacks, there would be no soul without a philosophy - one that has developed and changed over the life of the university.

In the mid-eighteenth century, during a period of twenty years, Columbia University (then Kings College), Princeton University, and Queen's College-now Rutgers-opened the doors of their respective institutions of higher learning. One can only speculate about the educational landscape today if the vote on a proposed merger between Princeton and Queen's had not been deferred, in 1793, when a yellow fever epidemic in Philadelphia led to sparse attendance at a Princeton Board of Trustees meeting. By the time the epidemic abated, the trustees at Queen's College had changed their minds and the two institutions have proceeded on separate paths that converge only occasionally for sport, rivalry, and, of late, for cooperative educational endeavors.

In 1773, when the first literary society at Queen's College tentatively began to build its library, electric lights were unheard of, and air conditioning, central heating, radios, television, telephone, telegraph, railroads, automobiles, and public libraries in every community were all in the future. Smoke alarms, access for the handicapped, and building codes were yet to be mandated. Consider that when the first student graduated from Queen's College in 1774 New Jersey was a colony and the Revolutionary War had yet to be fought. Although there is no specific mention of a library in early Queen's College records, books may have been provided for students' use from the tutors' private libraries. Today it would be unthinkable to consider opening a new college without a library, and the library would be an important factor in the college's accreditation. But the word "library" does not appear in early Queen's records even though the storage of books in an old chest and a closet is mentioned during the Revolutionary War. ${ }^{4}$

As early as 1773, the first literary society, the Athenian Society, was founded for the support of "learning which irradiates the Soul and dispels these Clouds of Ignorance... and to polish our Minds and beautify our Manners." As with the somewhat later literary and debating societies, Peithessophian, Philoclean, Calleopean, and the less-well- 
known Polemical and Federal Societies, a library was established for the use of members. The Athenian Society records indicate that a librarian attended the library every Monday for one hour and cared for the money belonging to the library and for the books. ${ }^{6}$ Although the exact disposition of the Athenian library is unknown, the library collections of societies established in the nineteenth century were integrated into the college library when the societies disbanded. The records of the Peithessophian Society, which appear to be the most complete in regard to the early library, lead one to assume a similar collecting pattern extended to the other societies as well-one that complemented rather than duplicated college-owned materials and provided a wider scope of intellectual endeavor than was generally fostered by the heavy emphasis in the college curriculum on classics and theology. ${ }^{7}$

It should also be understood that the thrust of late eighteenth-century education differed vastly from today, and that therefore the college library cannot be considered in the same terms as at present. ${ }^{8}$ The 1770 charter for Queen's was granted as a service to the Protestant Reformed Church, and the broad aim of the college was "for the education... in the learned languages, liberal and useful arts and sciences, and especially in divinity, preparing [students] for the ministry and other good offices." 9 Studies in those early years of the college included reading classical authors such as Cicero, Homer, and Xenophon, and receiving oral instruction in trigonometry, surveying, and astronomy. Chemistry was said to have "hardly reached any colleges." ${ }^{10}$ When the Dutch Reformed Church Theological Seminary moved to New Brunswick and joined with the college in 1810 , a climate was created in which the library was discussed more often, but acquisitions continued to be primarily through the gift of books-still in those days the most common way to enlarge a library collection.

Funding, an early and persistent problem at the college, led by 1812 to the proposal of a lottery to raise the funds that were needed to finish the "new college edifice" (the building now known as Old Queen's) and to purchase "a library and philosophical apparatus." ${ }^{11}$ By 1814, although Queen's Building remained incomplete, a "considerable library" was noted, a librarian appointed, and the princely sum of $\$ 100$ was allocated for book acquisitions. ${ }^{12}$ Between 1816 and 1825 the college was forced to suspend operations for lack of funds. When the college reopened, a section of the second floor of Queen's Building was devoted to the library, and this is the first mention of an actual commitment of space, by the college, for a library. Dr. Philip Milledoler, the college president 
in 1825 , described that library as "of such description as would scarcely bear the name, being mostly composed of Old Books in the Low Dutch." 13 There seems to have been conflicting opinion about the quality of the library, or the way it was being evaluated. Dr. Milledoler was, however, an advocate for the library, and a student was appointed as a librarian, whose job was to open the library for a most generous halfhour (between 8:30 and 9:00 a.m.) every Saturday morning. Clearly, reading in the library was not a popular or even a possible activity. ${ }^{14}$ In 1825, when the Peithessophian and Philoclean societies were formed, competing libraries were set up and were eventually to be located across the hall from each other in Van Nest Hall. Members of those societies, it is assumed, had much freer access to the society libraries than did nonmembers to the college collection.

So far we see little, if any, stress on libraries by the college. Up to this point, no importance was attached to services, and indeed they seem not to be thought of, nor was the necessity of a separate and unique building to house the collection recognized, probably because of the size and use patterns of the collection. From this somewhat haphazard beginning, Rutgers College Library continued to grow through the support of friends, faculty, and successive college presidents. By 1832, the first collected holdings of the college library were published in a small printed book, as was the custom of the day. The present collection would fill many volumes and shelves, but at that time all the holdings could be recorded in a thirty-four-page book that was little bigger than the palm of one's hand.

In 1843 the faculty called for a building to house the library and other departments. Despite the fact that Van Nest Hall, built in 1847, was initially meant to accommodate the library as well as a museum and laboratory, only the two literary societies, Peithessophian and Philoclean, moved their libraries into the building. ${ }^{15}$ The college library remained in Queen's awaiting future developments. When the Theological Seminary split away from the college in 1856-1857, the collection was divided between the two institutions, thereby reducing the volume count, but by 1871 the library was important enough (or perhaps students were more demanding) to justify an extension of the library's weekly opening time from one half hour to one-and-a-half hours (from 3:00 to 4:30 p.m.) on Friday afternoons. ${ }^{16}$ When the new Kirkpatrick Chapel was completed in 1873, a portion of the upper floor was provided for the library, ${ }^{17}$ and it was here that the library was to remain until overcrowding led to the benefaction of Ralph Voorhees that provided for the construction of 
Voorhees Hall, the first building that was planned, designed, and erected specifically as a library at Rutgers College.

By the time Voorhees Library opened in 1903 the collection had grown to 46,000 volumes. Interestingly, while the library had grown steadily but slowly over the first century and a quarter, the twentieth century has tested the abilities of everyone associated with the college and the library to predict trends and prepare for the growth of the university, demands of scholars, and burgeoning publications in virtually every field of scholarship. Voorhees Hall, ample in 1903 for the 200 students and 46,000 volumes, was no longer able to cope, even with expansion. By 1945 the students numbered over 2,200, library users had increased to over 6,000 , and the collection numbered 325,000 volumes. ${ }^{18}$ These figures were to be dwarfed in the aftermath of the second world war when increasing numbers of young men continued their education at Rutgers, making demands on many already less than adequate facilities.

And so the next phase of library building planning began. Alexander Library, opened in 1956 , was built to seat 1,200 , to provide work space for a staff of 60 , and had a capacity for one-and-a-half million volumes. This new library was conceived as a "teaching instrument" for scholars and students, and a lab for humanists and social scientists, ${ }^{19}$ a changing philosophy indicating the shift of focus of the library from a storehouse of books to a more vital and interactive element in the educational landscape of the university. The planning for this library, unlike that for earlier libraries at Rutgers, captured the interest of students and faculty alike. While the university librarian was planning the library from the inside out, analyzing services and collections, campus agitation was for an exterior that would be considered "modern architecture." The Rutgers public emphatically refused to accept any building designed in the Georgian or Colonial style. It was the university trustees who finally articulated the planning course that was to be taken. ${ }^{20}$ The interior was to be a "serviceable building for years to come," and the exterior, as befits a state-supported institution, was to provide aesthetics and, even in the landscape design, it was to reflect pride in the state with the construction of a New Jersey garden containing only plantings native to the state. ${ }^{21}$

Changing times were reflected by the growth of all areas of the college, an increase in the number and types of subjects studied, and the place that the library occupied in the college. During the nineteenth century the weekly half-hour opening of the library gave way to an hour- 
and-a-half and gradually to longer hours. During the twentieth century, student library staffing gave way to staffing by professional librarians who now must meet rigorous academic standards for faculty status. Changing times are reflected by students as well as libraries and their staffs. Among the many student restrictions in 1810 was the prohibition against playing hand or football or "any other game of diversion near the college building," and a dress code that cautioned students to avoid "all slovenliness and carefully to preserve a neat, cleanly and decent appearance," and required them to appear in black gowns at all public functions. ${ }^{22}$ In 1956, when the doors of the new Rutgers University Library were opened, the script for an innovative filmed freshman orientation to the library enumerated changes that had occurred in the Rutgers University Library since the early days of that institution (this orientation was for the gentlemen of the freshman class, for in 1956 women were not yet admitted to Rutgers College). The students learned from the film that the 1885 ruling requiring gentlemen to remove their hats upon entering the building was no longer enforced. Today's students may retain their hats but more often need to be asked to turn down the headphones that emit crackling sounds of rock and rap.

This library, the flagship of the Rutgers library system, was, in the beginning, at best only a book collection that was assembled less to serve the needs of the students and the curriculum than through the random addition of collections through the benefaction of college patrons. Today, in a time of rapid library growth and a saturation of information, each purchase or gift is carefully weighed for the value to the curriculum and to the research aim of the library and the university.

Today, technology is most central to library developments. Certainly no one in 1800 would have imagined the possibility, let alone the importance, of machinery for retrieving information. Yet today's library would be incomplete without telephones, fax machines, computers, microforms, CD-ROMs, and videodiscs. It is hard to imagine that only 100 years ago librarians were preoccupied with proper handwriting for catalog cards, finding it important to reach agreement about the acceptable size of the pen nib, and emphasizing the necessity for uniformity of handwriting. ${ }^{23}$ Typewriters were another source of controversy 100 years ago, and debate was often waged over the comparative readability of typed versus handwritten records and the relative speed with which each could be created. ${ }^{24}$ At the same time discussions about the value of electric (incandescent) lighting versus gas lamps were being conducted..$^{25}$ The issue of lighting was often resolved by opening the library only 
during daylight hours and having plenty of windows. In a 1912 discussion of library lighting, the effects of electricity upon humans was considered. ${ }^{26}$ Options for heating libraries included fireplaces, open fire grates, coal stoves, and gas or electric heaters; and of course fire buckets were recommended on every floor. ${ }^{27}$

While yesterday's library had windows that opened and no air conditioning, the new library will have no gas lamps and will have fixed windows, environmental controls, and be lit primarily by fluorescent lights. The main reference desk in Alexander Library is now equipped with telephones, including a cordless phone for use by reference staff when they must be away from the desk. In addition, fax machines provide almost instantaneous delivery of documents from distant points. The typewriter that eventually led to the demise of library handwriting has been made obsolete by computers. An online catalog that is rapidly making the card catalog obsolete serves to help the public locate books and periodicals. This online catalog (IRIS), implemented in 1983, provides the information found formerly in the card catalog and also indicates whether a book is on loan. Light pens used at the circulation desk scan information into a computer that maintains, in addition to the information of the card catalog, the information formerly held on the manual circulation cards. Of course, with the efficiency of the new technology and the growth of the college, some of the human touches have been lost. Few of today's students will be well known to the staff at the circulation desk, and it will be rare for any of that staff to know or care about the borrowing patterns of most students. This is in marked contrast to a 1938 explanation of why overdue fines were not needed: "Most of the students are known to the desk assistants, and if the written notice does not bring immediate response, the borrower is spoken to personally. We feel that in this way a more friendly atmosphere is created...." 28 Some things never change, and fines are still not assessed, but in an age of computer-generated overdue notices, the rationale is no longer the same.

The humanities or social science student of the '90s, served by the research collection in Alexander Library, can be found, like the student of science in the Library of Science and Medicine, seated or standing at a computer typing commands in order to locate information. In fact, with computer and modem, much of the initial work of locating material can be done in the comfort of a patron's home or office and the most convenient library location for the delivery of material can be specified. Indexes for journal articles are frequently supplied on CD-ROM or 
through interactive computer systems, with this sophisticated approach to information seeking being used from freshman year on. Two important computer operations have found a home in Alexander Library-the Lexicon Iconographicum Mythologiae Classicae, and the Center for Electronic Texts in the Humanities. Both are important for an international audience of scholars while greatly benefiting the humanities students and faculty at this university.

The use of new technological tools requires intensified student instruction. "Bibliographic Instruction" has become a required activity that teaches students to formulate and implement a methodology for research and also to navigate through the various forms in which information is sought and supplied. Such instruction has mushroomed in the late twentieth century, following the increasing professionalism of librarians. The new 1956 library, complex and relatively large, mandated that some form of orientation be given. The 1956 orientation script provided directions for filling out a bookcard when checking out a book, for the use of the card catalog, soon to be obsolete, and suggests that the reference staff, said to be available and willing to help, be asked for the location of encyclopedias, dictionaries, and directories. Orientation, rather than instruction, was what was given in 1956 and what formed the true precedents for today's BI. Today, students are provided with the locations of frequently used items such as those encyclopedias and dictionaries, but, more important, they are instructed in the intricacies of the various electronic and microform products and the ways they can be integrated into a methodology to complete class assignments and research. Of necessity, the sophistication of the media mandates that a new approach be made to information seeking and the construction of a research outline.

It is always risky to project the future, but clearly the consensus seems to be that technology will be the driving force, and ever-increasing types of materials will be delivered electronically. Some traditional methods of service and instruction will remain while new technologies will take over in other areas. Even now, upon entering the library and approaching the reference desk, students may use the Rutgers' hypercard system on a Macintosh computer for directions to materials in the library and to receive answers to commonly asked questions. "Miss Scarlett," developed by Rutgers' hypercard specialist Evelyn Greenberg, can easily navigate users through some of the more routine queries, making library users independent while allowing staff to concentrate on more specialized and/or complicated needs. Greenberg foresees ever greater use of 
and reliance upon the computer with the increased speed and efficiency of its applications. At the same time, others of the library faculty foresee computers as an enhancement for what they do now. Stan Nash, as BI coordinator, combines the traditional forms and approaches to information seeking with the more recent high-tech sources, seeing the basic need continuing - to help students approach the search for information with an understanding of what they want, what they need, and what and how to use the aids that are available so that the library experience is satisfying and useful. In fact, the ideal BI room and instruction of the future may go beyond demonstration to a fully-equipped laboratory where students will receive "hands on" experience with the various electronic utilities-from the use of the IRIS/OPAC system to such sophisticated utilities as, for example, the ARTFL database that allows users to search the texts of over 200 years of French literature.

The 1952 building program, citing the library's mission to serve as a research center, estimated the user population to be close to 9,000 with library holdings of approximately 400,000 volumes plus pamphlets, periodicals, government documents, and special collections. The service philosophy, the assistance provided to the undergraduate, was to enable him to become a scholar through the provision of important books and library resources, through the research function of the library, and through the cultural value of the rare materials in special collections. ${ }^{29}$

The library's concept document of 1989 demonstrates several changes. Described as the largest of all the Rutgers University libraries, Alexander Library houses the humanities and social sciences research collections, with the emphasis now being upon the research aspects of the collection since other libraries have been designated to serve undergraduate needs. In addition, the East Asian Library, the Special Collections and Archives, and the administrative offices for the combined university libraries are contained within this building. From the staff of sixty that Alexander was designed to accommodate, the staff now exceeds one hundred, augmented by more than one hundred additional student assistants. The user population has grown over these forty plus years to almost 30,000 , and the collection maintained in the building has grown to more than 800,000 volumes. The new emphasis is upon consolidating functions and increasing efficiency by increasing space for collections and users, improving environmental conditions, upgrading the building to satisfy the building codes, and the creation of an automated reference center that is necessary for a truly modern university library. 
The new reference area, in fact, will reflect a new attitude toward reference services and a greater awareness of the study atmosphere and library image. By defining the types of reference assistance provided in the library, a multi-use area, sectored for functions, will allow flexibility and efficiency. CD-ROMs and other electronic reference tools will be located in the automated reference center, while the reference desk itself will be adequately equipped with wiring and telephone lines to accept technology in the type and number needed on opening day, but also capable of expansion or adaptation for future changes. For the first time, a conscious, articulated effort is being made to eschew a "study hall atmosphere" and replace it with a "sense of a quiet place for serious research." 30

In 1938 the college reference librarians deemed it a "pleasant activity" to assist students not only with class work but also with outside activities and interests from "stuffing animals to repairing automobiles," ${ }^{31}$ but the image for the end of this century, and one that the newly designed space hopes to convey visually, will be reflective of the more serious research mission of the library-the library as the "intellectual center of the university." A "landmark destination" that is "sufficiently distinct architecturally" will be the visual manifestation of the library's philosophy and service. ${ }^{32}$

Student and faculty attitudes seem to be different from those that sought to influence the library form in 1956. A negative reaction to the possibility of a clock tower on the library was strongly voiced because it was felt that more practical considerations should be stressed at a time, not unlike that of the early years, of financial constraint.

Today, environmental concerns and building code compliance are the givens in building planning, while scholarly needs, especially technology, are the areas of debate, concern, and decision. In 1947, library building expert Ralph Ellsworth said that a researcher needed only a room to "read and write, think and calculate," and went on to argue for more seminar rooms and offices in which informality and messiness were to be encouraged. ${ }^{33}$ Literature after the 1980 s describes the library as a "marketplace of ideas" rather than merely a repository of works, ${ }^{34}$ the purpose of which is to acquire, store, and allow access to "carriers of knowledge" which may include electronic texts, video images, and computer software, and may extend to resource sharing among institutions. ${ }^{35}$ Words like "ideas" and "information" are supplanting the use of "books" in discussions of libraries and research. From the 1937 description of Rutgers library activities - book selection, book acquisition, book 
preparation, book preservation, and book interpretation [italics mine] ${ }^{36}$ to comments like "the decision of whether to enter the 'electronic age' is hardly negotiable for members of the scholarly community," 37 is a tremendous leap, but one to which the Rutgers University Libraries in general are committed.

Functionality and consolidation of services that guided the planning for this addition and renovation directly reflect the library's philosophical commitment to service. Although the motivating factor was the need for more space for seating and shelving, a great deal of study and thought has gone into providing space that will accommodate the kind of library that Alexander is today and that it plans to be at least through the first two decades of the next century. With almost fifty percent more space, adequate wiring and telephone lines to enhance the connection to the world at large, and attention to present building codes, the new structure will serve as an attractive, comfortable, and forward-looking core for the university community in which the intellectual needs of students and researchers can be met in the most comfortable, up-to-date, and efficient ways.

\section{Notes}

1 I am grateful to those who took the time to discuss the plans for the addition and renovation of Alexander Library: Marianne Gaunt, Kevin Mulcahy, Stanley Nash, and Evelyn Greenberg. I also would like to acknowledge the help received from the staff of Special Collections and Archives at a particularly difficult time in their operations.

2 Clyde Hendrick, "The University Library in the Twenty-First Century," College and Research Libraries 47, no. 2 (March 1986): 127.

${ }^{3}$ Governor Alfred E. Driscoll, at the dedication of the Rutgers University Library, November 16, 1956.

${ }^{4}$ Roy F. Nichols, "This Library We Dedicate," Journal of the Rutgers University Libraries (hereafter JRUL) 20, no. 1 (December 1956): 3.

Mildred R. Woodward, "The Athenian Society of Queen's College," JRUL 3, no. 1 (December 1939): 15.

6 Woodward, 18.

7 Francis A. Johns, "The Peithessophian Society Library Catalogue of 1834," JRUL 44, no. 2 (December 1982): 94, 97. Eschewing for the most part theology and classics that were stressed by the college, these collections tended rather to support literature, history, geography, and biography. All collections seemed to de-emphasize art, music, commerce, and science.

${ }^{8}$ George J. Lukac, ed. Aloud to Alma Mater (New Brunswick: Rutgers University Press, 1966), 16; and Johns, 98.

${ }^{9}$ William H.S. Demarest, A History of Rutgers College 1766-1924 (New Brunswick: Rutgers College, 1924), 75.

10 William Warren Blauvelt, "Early Nineteenth-Century Life at Queen's" in Aloud to Alma Mater, 24.

1 Philip G. Nordell, “The Lotteries" in Aloud to Alma Mater, 27. Muddy historical records suggest that although permission was received from the state, the results of the lottery were questionable. 
2 William H.S. Demarest, "History of the Library," JRUL 1, no. 1 (December 1937): 4.

Lukac, 41.

14 Demarest 1937, 4.

5 Demarest $1924,352$.

16 Demarest 1937, 6.

17 Ibid.

18 President Robert C. Clothier to the Board of 'Trustees, November 1, 1934.

19 Donald F. Cameron, "The New Library Building," JRUL 16, no. 2 (June 1953): $35-36$.

${ }^{20}$ Harvey S. Moskowitz, “A F ond Remembrance of Edward B. Wilkens, Rutgers First Planning Professor," JRUL 51, no. 1 (June 1989): 25. The directive of the trustees was that the "library must be a well-designed building of some distinction which will fittingly represent Rutgers University, must be harmonious with other buildings...planned as a library and built...from the inside out."

${ }^{21}$ Cameron 1953, 33-36.

22 Demarest 1924, 227-29.

23 From the proceedings of the Lake George Conference of Librarians, September 1885, in Library Journal 10, no. 9-10 (September-October 1885): 321.

${ }^{24}$ Ibid, 320-32.

25 Ibid, 333-35.

${ }^{26}$ Charles C. Soule, How to Plan a Library Building for Library Work (Boston: Boston Book Co., 1912), 192, 201.

27 Ibid, 210-12, 221.

${ }^{2 k}$ Ellen P. Campbell, "Student Use of the Library," JRUL 2 (December 1938 \& June 1939): 22.

${ }_{29}$ Draft of the building program, August 28, 1952.

30 Kevin Mulcahy, in a description to the author of the concept and configuration of the new reference area.

31 Campbell, 23.

32 Alexander Program Report, January 12, 1990.

${ }_{33}$ Ralph E. Ellsworth, "The Library Building and the Reader" in Library Buildings for Library Service, ed. by Herman H. Fussler. (Chicago: American Library Association, 1947), 33.

${ }^{34}$ Ronald J. Heckart, "The Library as a Marketplace of Ideas," College and Research Libraries 52, no. 6 (November 1991): 497.

${ }^{35}$ Michael Gorman, "The Academic Library in the Year 2001, Dream or Nightmare or Something in Between," Journal of Academic Librarianship 17, no. 1 (March 1991): 6.

36 William H. Randall, "Report on the Library Situation at Rutgers University," November, 1937.

37 Czeslaw Jan Grycz, "Economic Models for Disseminating Scholarly Information," ALCTS Nerwstetter 3, no. 2 (1992): 9. 


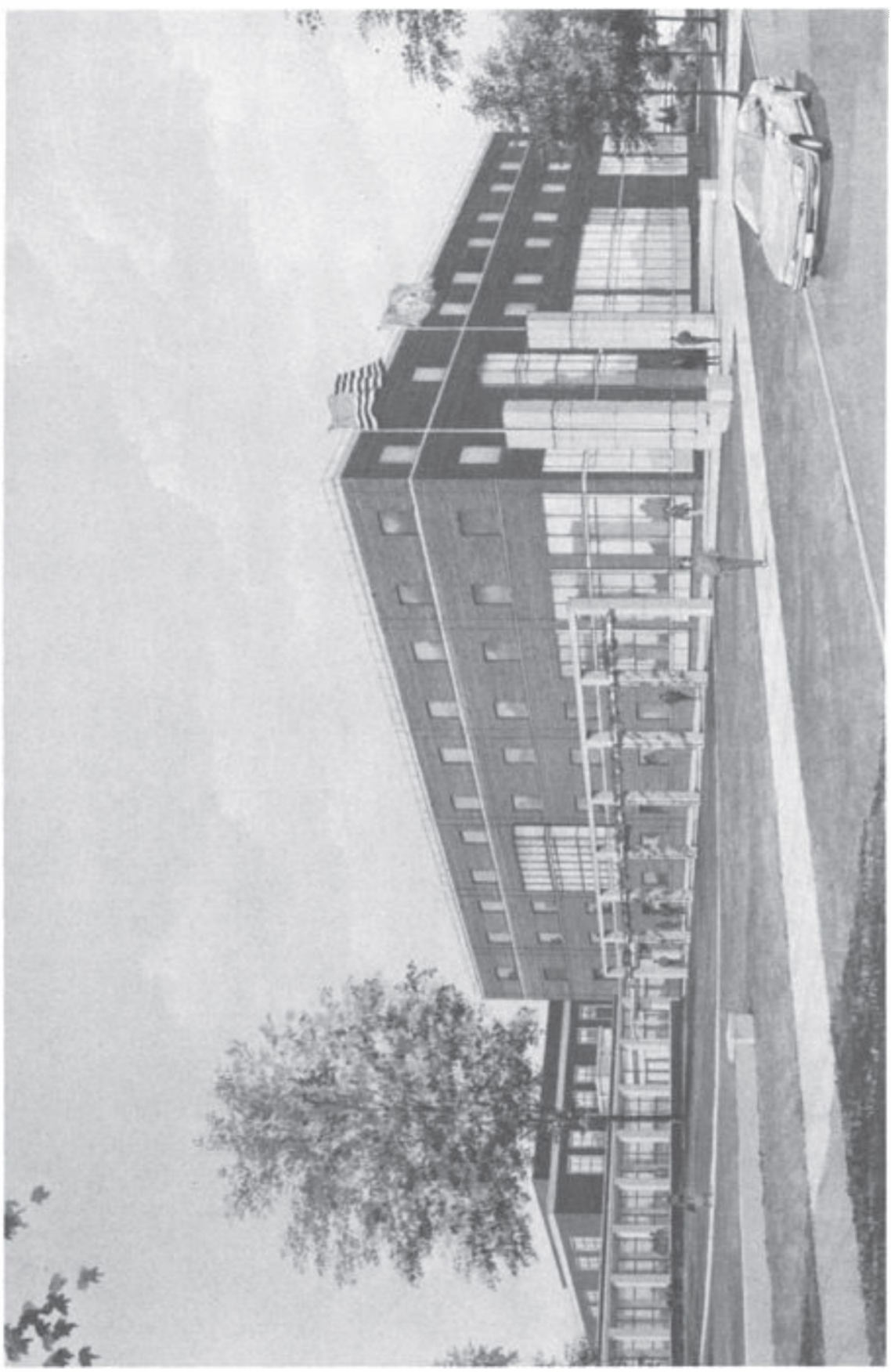

Fig. 1.1 Architect's Rendering of Enlarged and Renovated Alexander Library 


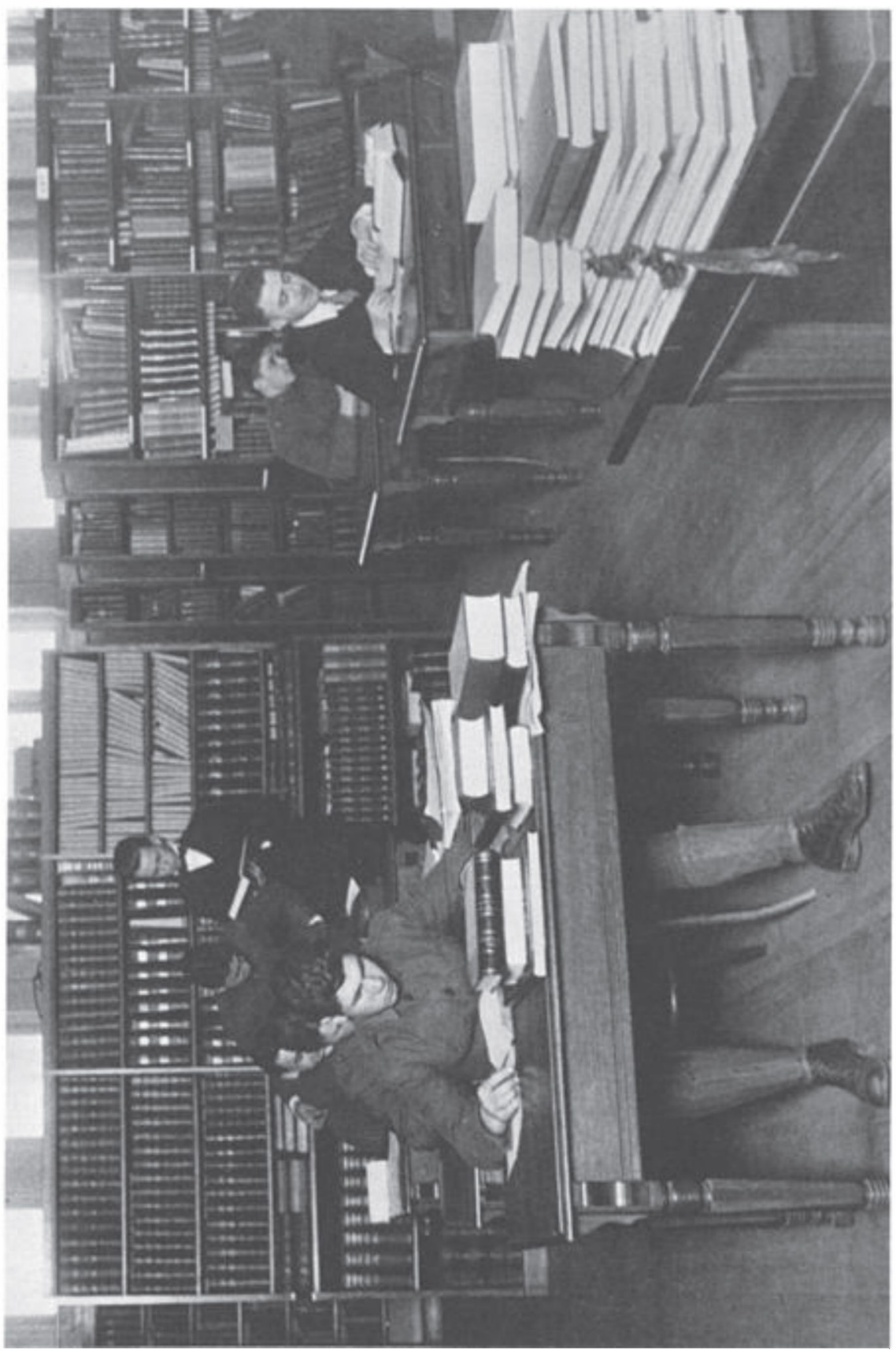

Fig. 1.2 Turn-of-the-century Students in Voorhees Library (Photograph: Special Collections, Rutgers University) 